\title{
Child rearing and cultural diversity. Contributions of anthropology to pediatric practice
}

\author{
María A. Colangelo, M.D. ${ }^{a}$
}

\begin{abstract}
This article proposes to define child rearing as a social and cultural process that, far from depicting universal and invariable characteristics, shows a huge diversity, mostly linked to the cultural features of families and communities in charge of such process. It has been considered that the anthropological perspective may contribute to understanding such multiple forms of bringing up children that are usually seen at the pediatrician's office and that involve different concepts in relation to childhood, individual, body, motherhood, fatherhood, among others. In turn, this article warns about the risks of restricting the approach to child rearing to a naive cultural relativism that reduces the role of culture to essentials and, on the contrary, points out the need to consider how cultural features intertwine with social inequalities when interpreting such diversity.

Key words: child rearing, cultural diversity, social inequality.
\end{abstract}

http: / / dx.doi.org/ 10.5546/ aap.2020.eng.e379

(Centro de Estudios en Nutrición y Desarrollo Infantil, CEREN), CIC/PBA La Plata, province of Buenos Aires, Argentina.

E-mail address:

María A. Colangelo, M.D.: adecolangelo@yahoo.

com.ar

Funding:

This study was conducted in the context of a research plan accredited and funded by the Scientific Research Council of the province of Buenos Aires (Comisión de Investigaciones Científicas de la Provincia de Buenos Aires, CIC/PBA); María A. Colangelo, M.D., is an investigator working for such organization.

Conflict of interest: None.

Received: 3-1-2019 Accepted: 11-14-2019 depicting universal and invariable characteristics, child rearing practices are hugely diverse. Such diversity is seen in different manners inside the pediatrician's office and leads to new and numerous questions in a profession that was developed and consolidated in the context of an allegedly homogeneous and universal concept of childhood.

Actually, medical knowledge was part of the processes that, since the $18^{\text {th }}$ century, allowed to define an adequate child rearing in association with a nuclear family, motherhood focused on care, and a childhood model that highlighted immaturity, malleability, and dependence..$^{1-3}$ Based on such hegemonic patterns, how should other child rearing models that do not fit the proposed guidelines be considered? How should differences be faced?

Based on these questions, this article proposes to describe the culturally and socially developed nature of the child rearing process in an attempt to understand its heterogeneity, complexity, and approach. To this end, it resorts to social anthropology, which focuses its interests on a socially positioned human experience diversity and understanding social phenomena based on the perspectives of social actors themselves: the so-called native's or other culture's point of view.

The proposed anthropological approach considers that the cultural diversity and social inequality domains are closely intertwined with child care, and this is useful to warn about the limits of cultural relativism in poverty and rights violation situations. From this perspective, aimed at not overlooking the complexity of social phenomena, the belief is that the multiple child 
rearing methods usually seen by pediatricians may be assessed in terms of a contribution so as to reconsider health care providers' suppositions about child rearing.

\section{THE SOCIOCULTURAL NATURE OF THE CHILD REARING PROCESS}

The diversity of child rearing practices evidences the social and cultural nature -i.e., not marked by biological, innate processes- of how the rearing process has evolved. Given the defenselessness in which human beings are born and the impossibility to warrant their care based on adults' instinctive behaviors, each society has to develop its own conventional mechanisms that would allow to introduce its new members into the world of social relations and cultural meanings.

All societies develop and implement child rearing practices. To that end, and together, they develop theoretical and practical knowledge about child care and education, which allow to define, more or less explicitly and always questioned, the adequate method to care for children, as well as to teach them behaviors that are expected, valued or not allowed in such social group. The child rearing process involves child care and development practices, especially in the first stages of their lives.

In this process, children themselves are far from being passive because they question the definitions devised by adults and force them to explain and reformulate them continuously. The studies focused on what is known as childhood anthropology have reanalyzed rearing and socialization by showing that children are not just immature recipients of a finished social product developed exclusively by adults, but social actors actively involved in their accommodation into social life and cultural production, and who build meanings and social relations based on their experience and interaction. ${ }^{4-8}$

Each daily action carried out to raise a child (in relation to their feeding, hygiene, dressing, and sleeping), regardless of how insignificant or routine it may seem, implicitly involves a series of representations about childhood and a child's body which, in turn, refer to broader concepts about an individual, the course of life, family, motherhood, fatherhood, and social ties. Anthropological studies focused on early childhood ${ }^{9-11}$ give an account of the ritual dimension that accompanies such routine care provided to a baby's body, which involves not only the parents but also a broader social network of which the baby is part. In turn, they position child care as a body technique, a ritual, and a process that is involved in the development of children's and their family's identity and social status and, at the same time, reveals them.

For example, in Andean communities that speak Quechua, newborn care involves breastfeeding, cleaning, and wrapping them with several blankets, and also complying with placenta-related rituals, which is considered a younger sibling. If the placenta is not properly buried, it is considered a severe child rearing error because it implies serious consequences on children development as a human being. Thus, "through child care methods, societies express their vision of the world, their value system, their representations of life and death" ${ }^{12}$

Therefore, rearing processes mean much more than a set of daily child care practices; they play a central role in the development of a person as defined by each society. The development of a person refers to the social definition of humanity, the processes which, in the setting of each culture, are considered necessary for an individual to acquire the attribute of human being and the way society interferes in such processes, which are continuous and not finite. Since it is a socially- and culturally-mediated experience, the development of a person is not necessarily correlated to conception or birth nor does it start or end at the same time in all societies. For example, in several societies, newborn infants do not exist in terms of a full human being, they transform into a person after a long and arduous process, which ends several months after birth and requires certain rituals for it to be successful.

In the urban, middle-class, western model that emerged in modernity, child rearing should ideally take place in the private context of the household and by both parents, especially the mother, who is mostly hold liable for its success. However, this process is seen as something too risky to be solved exclusively in the family circle, so it requires expert supervision, which encompasses pediatricians. This place of medical knowledge is not inherent to child care but results from its hygienic intervention with the families and child rearing medicalization, generated since the end of the $18^{\text {th }}$ century through motherhood reinforcement and teaching, put on level with femininity. 2,3,13,14

In this context, child rearing practices point to a progressive skill acquisition so that the child gradually gains physical and mental 
independence, with the child considered as a single individual with a future personal project to be deployed, in the framework of a specific person development process that has emerged in modern times and brings the person into line with the concept of an individual.

However, child rearing models of other sociocultural groups emphasize that the child should be recognized as a member and complement of their group, which is also responsible for their care and education. In this case, the person develops as part of a collective (lineage, clan, extended family, caste): a human being may only exist as a singularity in the context of their community. A child's social value does not lie in their individuality but in their link nature, connecting generations and belonging to the group and to their parents. Therefore, kinship and community relations are central to understand and address problems related to bringing up children and their health.

\section{CULTURAL DIVERSITY AND SOCIAL INEQUALITY: TWO INTERTWINED DOMAINS IN THE CHILD REARING PROCESS}

Up to this point, the role of cultural features in child rearing has been evidenced. Now it is necessary to approach it in greater depth, considering that practices and representations at stake do not take place in a historical and political void and are not carried out by an isolated, homogeneous community. Rather, admitting the dynamic and conflicting nature of social life, it is necessary to recognize that, in settings like ours, cultural diversity -mostly linked to a particular ethnicity- takes place in a deeply unequal society.

In other words, although culture is a key element in the development of child rearing methods, and cannot be omitted in its approach, it is not the only type of social process involved and does not occur isolated from other social relations or beyond historical transformations. Not all child care and development practices result from cultural choices; many of them derive from socioeconomic conditions affecting families and communities according to their social status. This aims to warn about certain essentialist and ahistorical uses of culture that present it out of context and in a crystallized manner, and entail the risk of giving a popular character to poverty by taking practices and representations as a product of cultural options when they actually derive from social inequality and rights violation (e.g., certain communications have attributed malnutrition in Wichí children in the northern regions of Argentina to cultural practices). ${ }^{15}$

On the contrary, the proposed approach implies considering child care systems both as a product of knowledge construct and practices by different social groups and as structural emerging factors of historical conditions in a given society, i.e., perceiving that other or different rearing practices include elements that correspond to cultural options and also other elements derived from poverty and rights violation. As stated by Ortale and Santos, ${ }^{16}$ care actions that make up child rearing are based on cultural patterns, personal beliefs, and other acquired knowledge, and also on the factual possibilities available for caregivers.

Therefore, the interaction of these two domains (cultural diversity and social inequality) enables the possibility of analyzing social childhood problems in their full depth and appears to be particularly indispensable when addressing disagreements about child rearing that take place during pediatric office visits. From this perspective, for example, it is difficult to attribute, in advance, nutrition problems in an indigenous child to cultural guidelines or family customs. Rather, the question we should be asking is about indigenous peoples' possibilities to deploy their child rearing practices and provide a healthy nutrition according to their cultural parameters in a setting of dispossession from their territories, cornering at unproductive areas, frequently vulnerable migratory processes, and breakdown of community ties. ${ }^{17-19}$

Therefore, when working with cultural diversity, the perspective known as interculturality is superior to that of cultural relativism. The latter recognizes different practices as a product of particular cultural constructs that are worthy of respect. However, when considering each culture in itself, developing independently, we end up leaving class relations, socioeconomic processes, as well as the resulting conflicts and contradictions, out of the equation.

The interculturality concept, as advised by Ramírez Hita, is not exempt from essentialist and culturalist uses either when it is reduced to a complement between traditional medicine and biomedicine, each taken as a homogeneous and pure set of practices and representations. ${ }^{20} \mathrm{On}$ the contrary, in a critical sense, interculturality aims at considering the potential dialogs among cultural groups based on the discussion of the 
power and conflict relations affecting them and their position in the broader social structure of which they are part. This requires keeping in mind the idea of health care quality, including the complexity entailed by its definition, which is what the members of different social groups tend to look for when they attend a physician's office in the formal health care system.

This path allows us to position child rearing in the framework of broader social processes embedded in the social organization of care, and this implies considering the role played not only by the families, but also by the government and its agencies, the market, and different social organizations in everyday child care. ${ }^{21}$ Such viewpoint makes it possible to question the public/private space dichotomy that is usually the basis for considering child rearing so that we may be able to analyze the continuum existing among care in the domestic space, cultural features, and social forces determining household conditions.

\section{FINAL CONSIDERATIONS}

The sociocultural aspect of child rearing was addressed taking into consideration the multiple relations and processes involved in it. This allows to state that the rearing method not only depends on personal or family customs but on the complex manner in which practices and meanings related to childhood, the individual, life cycle, motherhood, fatherhood, etc. are combined and developed collectively by the different cultural groups throughout their history.

Likewise, it has been pointed out that it is necessary to recognize cultural diversity, but this is not enough to understand the different manners of raising children that may be seen by a pediatrician. Actually, considering the inequalities of our society, we can no longer ignore the way socioeconomic conditions shape child rearing, thus limiting the options of those responsible for bringing up children.

Cultural diversity does not disappear as an essential domain of child rearing, but it cannot be considered in itself but as deeply intertwined with social class differences. It is at the specific intersection of these two coordinates (cultural diversity and social inequality) that each social group implements a series of guidelines through which children internalize the behaviors, thoughts, and feelings of the group to which they belong and, at the same time, acquire their personal identity. In addition to these domains, we find the gender domain, cross-sectional to the other two, but which has not been analyzed here because of lack of space.

Now, how could pediatric practice be benefited from recognizing other child rearing methods and the multiple aspects involved in them? First of all, by assuming that these practices imply knowledge and that there are no human groups that lack child rearing guidelines. This means that, even if we find them odd, and unless they entail pathological manifestations, these guidelines are not whimsical or random; instead, they gain meaning in the framework of a set of concepts and relations typical of a society and its culture. This is an invitation to opening our point of view towards the broader group as a unit of social organization when addressing child rearing. If we look to understand it only from one nuclear family-centered model, we will miss the chance to understand the logic of several practices, which would be taken to the non-rational or abnormal field.

However, recognizing this implies advising that pediatricians' routine practice does not take place with an abstract childhood but in the presence of real children in a particular position: children born in a specific type of family or community, growing up in a suburban neighborhood, in the center of a large city or in a rural town, feeling part of a minority ethnic group or a national community, and belonging to one or other social class. Therefore, it is impossible to understand children as subjects and interpret what they are going through without considering them as members of a social group and in a historical moment during which their childhood takes place.

The recognition of cultural diversity and social inequality in child rearing processes aims at establishing other types of pediatric health care approaches that include differences in an unbiased manner. Recognizing other child rearing methods is not enough, it is necessary to take into account how we relate them to the ways we were brought up: Are they a barrier? An eccentric feature? Or a contribution? This will depend on the place assigned to that other individual who challenges our certainties every time they manifest their different practices and representations during the pediatric office visit. If recognized as a full individual, although we may not completely agree with their point of view, it will be possible to establish a dialog that implies actually listening to the other person because we 
are assuming that they know about child rearing and have something to say about it.

So, this is not about dismantling the differences through a patronizing perspective or kindly tolerating them, but considering the other as a valid agent with whom we may not necessarily agree but with whom we may exchange knowledge and even argue. Only this way it will be possible to consider child rearing not for children or by their families and communities, but together with them.

\section{REFERENCES}

1. Ariès P. História social da criança e da família. 2da ed. Rio de Janeiro: Guanabara; 1986.

2. DarréS. Maternidad y tecnologías de género. Buenos Aires: Katz; 2013.

3. Nari M. Políticas de maternidad y maternalismo político. Buenos Aires: Biblos; 2004.

4. Cohn C. Antropologia da criança. Rio de Janeiro: Jorge Zahar Ed; 2005.

5. Nunes A. A Sociedade das CriançasA'uwe-Xavante. Por umaantropologia da criança. Lisboa: Instituto de Inovação Educacional; 1999.

6. Pires F. Ser adulta e pesquisar crianças: explorando possibilidades metodológicas na pesquisa antropológica. Rev Antropol. 2007; 50(1):225-70.

7. Szulc A. Antropología y Niñez: de la omisión a las "culturas infantiles". In: Wilde G, Schamber P (eds.). Cultura, comunidades y procesos contemporáneos. Buenos Aires: SB; 2006.Pages 25-51.

8. SzulcA.Laniñezmapuche:sentidos depertenenciaentensión. Buenos Aires: Biblos; 2015.

9. Bonnet D, Pourchez L. Du soin au rite dansl'enfance. Toulouse: Érès-IRD; 2010.

10. Cohn C. Crescendo comoumXikrin: uma análise da infancia e do desenvolvimento infantil entre os Kayapó-Xikrin do Bacajá. Rev Antropol. 2000; 43(2):195-222.

11. Gottlieb A. Where have all the babies gone? Toward an anthropology of infants and their caretakers. Anthropol $Q$. 2000; 73(3):121-32.
12. Bonnet D. Argumentos para un enfoque global de la pediatría. Salud, crecimiento y desarrollo del niño. In: De Suremain CE, Lefevre P, Rubín de Celis E, Cejas E (eds.). Miradas cruzadas en el niño: un enfoque interdisciplinario para la salud, el crecimiento y el desarrollo del niño en Bolivia y Perú. La Paz: Plural; 2003:9-22.

13. Donzelot J. La policía de las familias. Valencia: Pre-Textos; 1990.

14. Colangelo MA. La crianza en disputa: medicalización del cuidado infantil en Argentina entre 1890 y 1930. [Doctoral programdissertation]. La Plata: Facultad de Ciencias Naturales y Museo, UNLP; 2012.

15. Guerra N. Salta. El Ministro atribuye a un té de anís y poleo la última muerte de una niña wichí. Revista Norte. Salta, 14 de noviembre de 2016. [Accessed on: November $5^{\text {th }}, 2019$ ]. Available at:http:/ / revistanorte.com.ar/salta-el-ministroatribuye-a-un-te-de-anis-y-poleo-la-ultima-muerte-deuna-nina-wichi/.

16. Ortale S, Santos J. Crianza: un estudio de los patrones de crianza en el partido de La Plata. Buenos Aires: El Aleph; 2014.

17. Lorenzetti M. Del "capital social" a la "culturalización dela pobreza": la construcción de alteridad en los programas de salud para la población indígena. IV Jornadas de Jóvenes Investigadores. Del 19 al 21 de septiembre de 2007. Instituto de Investigaciones Gino Germani, Facultad de Ciencias Sociales. Buenos Aires; 2007.

18. Leavy MP. Aportes para pensar el flagelo de la desnutrición desde la antropología de la infancia. Horiz Sociol. 2015; 3(6):54-72.

19. Leavy MP, Szulc A, AnzelinI.Niñezindígenay desnutrición: análisis antropológico comparativo de la implementación de programas alimentarios en Colombia y Argentina. Cuad Antropol Soc. 2018; 48:39-54.

20. Ramírez Hita S. Políticas de salud basadas en el concepto de interculturalidad: los centros de salud intercultural en Bolivia. IX Congreso Argentino de Antropología Social. Del 5 al 8 de agosto de 2008. Facultad de Humanidades y Ciencias Sociales, UNaM. Posadas, Argentina; 2008.

21. Faur E. El cuidado infantil en el siglo XX. Mujeres malabaristas en una sociedad desigual. Buenos Aires: Siglo Veintiuno; 2014. 